\title{
Seleksi Toleransi Kekeringan In Vitro terhadap Enam Belas Aksesi Tanaman Terung (Solanum melongena L. ) dengan Polietilena Glikol (PEG)
}

\author{
In Vitro Selection of Sixteen of Eggplant (Solanum melongena L. ) Accessions to Drought \\ with Tolerance Polyethylene Glycol (PEG)
}

\author{
Erna Sinaga $^{1}$, Megayani Sri Rahayu ${ }^{1}$, dan Awang Maharijaya ${ }^{{ }^{*}}$ \\ Diterima 18 November 2014/Disetujui 27 Februari 2015
}

\begin{abstract}
The objectives of this study were to study the effect of several concentrations of polyethylene glycol (PEG) on the in vitro growth of eggplant, to find the appropriate PEG concentration for in vitro selection to drought tolerance of eggplant and the drought tolerant eggplant accessions. The experiment was conducted at the Laboratory of Tissue Culture, Department of Agronomy and Horticulture, Bogor Agricultural University. The experiment was arranged in a completely randomized design with two factor. The first factor was concentration of PEG $(0,5,10$, and 15\%) while the second factor was eggplant accessions (Kania F1, 001, 007, 013, 016, 030, 034, 035, 055, 057, 069, 071,072, 078, 085, and 090). The results showed that the addition of PEG to in vitro media significantly affected the survival percentage, the percentage of callus, developed the bud and the number of leaves of eggplant. Addition of PEG 10 and $15 \%$ in media can be used as the drought tolerance selective agent of eggplant in vitro. Kania F1, 001, 007, 016, 034, 035, 055, 057, 069, 071, 072, 078, 085, and 090 were eggplant accessions which might be tolerant to drought.
\end{abstract}

Keywords: in vitro selection, solanaceae, tissue culture, tolerant, drought

\begin{abstract}
ABSTRAK
Penelitian ini bertujuan untuk mempelajari pengaruh beberapa konsentrasi polietilena glikol (PEG) terhadap pertumbuhan tanaman terung in vitro, mendapatkan konsentrasi PEG yang dapat digunakan untuk seleksi tanaman terung secara in vitro dan nomor terung toleran terhadap cekaman kekeringan. Penelitian ini dilaksanakan di laboratorium Kultur Jaringan, Departemen Agronomi dan Hortikultura, Institut Pertanian Bogor. Penelitian ini disusun dalam rancangan acak lengkap dua faktor. Faktor pertama adalah konsentrasi PEG terdiri atas 0, 5, 10, dan 15\%. Faktor kedua adalah nomor terung terdiri atas enam belas nomor (Kania F1, 001, 007, 013, 016, 030, 034, 035, 055, 057, 069, 071, 072, 078, 085, dan 090). Hasil penelitian menunjukkan bahwa penambahan PEG pada media in vitro memberikan pengaruh nyata dan sangat nyata terhadap persentase hidup eksplan, persentase eksplan berkalus, pertambahan tinggi tunas, dan jumlah daun tanaman terung. Media PEG 10 dan $15 \%$ merupakan media yang dapat digunakan untuk seleksi kekeringan tanaman terung in vitro. Nomor terung Kania F1, 001, 007, 016, 034, 035, 055, 057, 069, 071, 072, 078, 085, dan 090 merupakan nomor-nomor terung yang toleran terhadap cekaman kekeringan.
\end{abstract}

Kata kunci: kultur jaringan, seleksi in vitro, solanaceae, toleran kekeringan

\section{PENDAHULUAN}

Terung (Solanum melongena L.) merupakan salah satu tanaman sayuran asli daerah tropik yang cukup terkenal di Indonesia dan mudah ditemukan di pasar tradisional dengan harga relatif murah. Buah terung mengandung vitamin A, B1, B2, dan unsur

\footnotetext{
${ }^{1}$ Departemen Agronomi dan Hortikultura, Fakultas Pertanian, Institut Pertanian Bogor

(Bogor Agricultural University), Jl. Meranti, Kampus IPB Darmaga, Bogor 16680, Indonesia

Telp.\&Faks.62-251-8629353.*Email korespondensi: awang.maharijaya@gmail.com
} 
fosfor serta memiliki manfaat sebagai obat tradisional seperti obat gatal pada kulit, obat sakit gigi, wasir dan tekanan darah tinggi (Hastuti, 2007). Prospek pengembangan komoditas sayuran di Indonesia sangat baik karena memiliki nilai ekonomi yang tinggi dan potensi pasar yang terbuka lebar, baik di dalam negeri maupun luar negeri (Zulkarnain, 2010). Terung merupakan salah satu sayuran yang memiliki potensi sangat baik untuk dikembangkan di Indonesia.

Produksi terung nasional dari tahun 1997 hingga 2013 yaitu sebanyak 279516 ton tahun $^{-1}$ hingga mencapai 519646 ton tahun ${ }^{-1}$ (BPS, 2014). Produksi terung Indonesia tersebut masih tergolong rendah. Menurut data FAO (2012) produksi terung Indonesia menempati posisi keenam di dunia dengan nilai produksi sebesar 518827 ton, jauh lebih rendah dibandingkan China yang mencapai produksi 28800000 ton sehingga pengembangan tanaman terung perlu dilakukan untuk meningkatkan produksi terung nasional.

Cekaman kekeringan merupakan salah satu permasalahan utama yang terjadi pada lahan-lahan pertanaman. Pemanasan global mengakibatkan perubahan iklim yang tidak menentu dan menurunnya ketersediaan air tanah akibat dari persaingan penggunaan air tanah untuk kebutuhan industri (Efendi et al., 2010). Hal tersebut menjadikan lahan pertanaman tidak selamanya ideal untuk pertumbuhan tanaman sehingga pengembangan jenis terung yang toleran kekeringan perlu dilakukan demi peningkatan produksi terung nasional. Program ekstensifikasi pertanian saat ini pun hanya dapat dilakukan dengan pembukaan areal yang umumnya marjinal, seperti pemanfaatan lahan kering dengan kendala cekaman kekeringan.

Salah satu tahapan metode yang dapat dilakukan dalam mengembangkan tanaman terung toleran kekeringan adalah seleksi kekeringan berbagai jenis terung secara in vitro. Penggunaan seleksi in vitro merupakan alternatif untuk mendapatkan tanaman toleran cekaman kekeringan. Indriani et al. (2009) menyatakan bahwa seleksi toleransi kekeringan tanaman kedelai secara in vitro dapat dilakukan dengan memberikan simulasi kekeringan dengan menggunakan polyethylene glycol (PEG). Senyawa polyethylene glycol (PEG) merupakan senyawa yang dapat menurunkan potensial osmotik larutan melalui aktivitas matriks sub-unit etilena oksida yang mampu mengikat molekul air dengan ikatan hidrogen.

Penggunaan larutan PEG 6000 dengan konsentrasi $5-20 \%$ pada media in vitro diharapkan dapat menciptakan potensial osmotik yang setara dengan kondisi tanah kapasitas lapang dan titik kelembaban kritis sehingga eksplan memberikan respon yang sama dengan tanaman yang mengalami cekaman di lapangan (Rahayu et al., 2005). Penelitian ini bertujuan untuk mempelajari pengaruh beberapa konsentrasi PEG terhadap pertumbuhan tanaman terung in vitro, mendapatkan konsentrasi PEG yang dapat digunakan untuk seleksi kekeringan tanaman terung secara in vitro dan mendapatkan nomor terung toleran terhadap cekaman kekeringan.

\section{BAHAN DAN METODE}

Penelitian ini dilaksanakan di laboratorium Kultur Jaringan, Departemen Agronomi dan Hortikultura, Fakultas Pertanian, Institut Pertanian Bogor pada bulan Januari - Juli 2014. Penelitian seleksi kekeringan ini menggunakan enam belas nomor tanaman terung sebagai bahan tanaman yang akan diseleksi. Enam belas nomor tanaman terung tersebut berasal dari petani-petani terung daerah lahan pertanian yang cenderung kering.

Bahan tanaman yang digunakan pada penelitian ini yaitu bahan tanaman yang berupa stek satu mata tunas dari planlet enam belas nomor tanaman terung (Kania F1, 001, 007, 013, 016, 030, 034, 035, 055, 057, 069, 071, 072, 078, 085, dan 090 ). Bahan media kultur Murashige dan Skoog (MS) yang digunakan meliputi agar sebagai bahan pemadat, akuades, gula, kertas saring, dan busa. Bahan kimia yang digunakan meliputi alkohol 96\% dan bahan pemutih komersial yang mengandung natrium hipoklorit, $\mathrm{KOH} 1$ $\mathrm{N}$ sebagai pengatur keasaman larutan media, dan polyethylene glycols (PEG) 6000.

Penelitian ini disusun menurut rancangan acak lengkap (RAL) secara faktorial. Faktor dalam penelitian ini yaitu nomor terung dan konsentrasi PEG. Perlakuan nomor terung yang terdiri atas enam belas nomor (Kania F1, 001, 007, 013, 016, 030, 034, 035, 055, 057, 069, 071, 072, 078, 085, dan 090) dan perlakuan konsentrasi PEG terdiri atas 0, 5, 10, dan $15 \%$ yang setara dengan tekanan osmotik 
0 Mpa (PEG 0\%), -0,13 Mpa (PEG 5\%), -0,19 Mpa (PEG 10\%), dan -0,41 Mpa (PEG 15\%) (Mexal et al., 1975). Penambahan PEG dalam media menyebabkan media akan menjadi cair (medium cair) sehingga untuk mencegah eksplan tidak tenggelam maka digunakan busa dan kertas saring. Eksplan yang digunakan pada media perlakuan PEG berupa stek satu mata tunas dengan ukuran $0.5 \mathrm{~cm}$ yang diperoleh dari planlet tanaman terung hasil subkultur. Eksplan ditanam di atas busa yang telah dilubangi dengan diameter $2 \mathrm{~mm}$ pada media perlakuan yang berupa media cair.

Unit percobaan terdiri atas satu botol kultur yang ditanami empat eksplan yang berupa stek satu mata tunas tanaman terung. Tiap kombinasi perlakuan diulang tiga kali. Total botol kultur yaitu 192 botol dengan total 768 eksplan. Pengamatan meliputi persentase eksplan hidup, persentase eksplan berkalus, pertambahan tinggi tunas, dan jumlah daun. Analisis ragam dilakukan terhadap data. Jika uji $\mathrm{F}$ berbeda nyata, dilanjutkan dengan uji jarak beganda Duncan (Duncan Multiple Range Test/DMRT).

\section{HASIL DAN PEMBAHASAN}

\section{Kondisi Umum Penelitian}

Penelitian diawali dengan mengecambahkan benih terung pada media MS0 selama dua minggu. Elimasni et al. (2006) menyatakan bahwa media MS0 adalah media yang terbaik untuk proliferasi dan diferensiasi eksplan tanaman terung secara in vitro. Perbanyakan planlet dilakukan dengan subkultur epikotil tanaman terung pada media MS0 selama empat minggu.

Benih tanaman terung tumbuh dengan baik selama dua minggu proses perkecambahan.
Setelah dua minggu, epikotil tanaman dipotong dan ditanam pada media subkultur MS0. Tanaman terung subkultur terlihat steril dan tumbuh dengan baik pada pengamatan minggu pertama dan kedua. Eksplan epikotil mulai membentuk kalus dan akar pada minggu pertama, lalu mulai mengalami pertambahan tinggi, jumlah tunas, dan jumlah daun pada minggu kedua hingga minggu keempat. Beberapa tanaman terung mulai terlihat terkontaminasi pada minggu ketiga subkultur. Kontaminasi yang terlihat disebabkan oleh cendawan dan bakteri. Cendawan dan bakteri yang tumbuh berasal dari pinggir botol dan permukaan media. Kontaminasi dapat muncul karena kurang sterilnya proses subkultur dan kondisi lingkungan.

Kondisi eksplan tanaman terung pada minggu pertama masih terlihat segar pada setiap media perlakuan. Kondisi eksplan tanaman terung mulai terlihat mengalami perbedaan antar media perlakuan pada 2 MSP dan 3 MSP. Pada 3 MSP, eksplan pada PEG $0 \%$ terlihat tetap segar dan tumbuh dengan baik, eksplan pada PEG 5\% sebagian besar terlihat tetap berwarna hijau tetapi pertumbuhan tunasnya kerdil dan menghasilkan daun yang sedikit, eksplan pada PEG 10\% sebagian besar terlihat menguning kecoklatan, dan eksplan pada PEG 15\% sebagian besar terlihat berwarna coklat (mati).

\section{Persentase Hidup Eksplan}

Persentase hidup eksplan tanaman terung dilihat dari warna eksplan tanaman terung. Tanaman yang berwarna hijau merupakan tanaman yang masih hidup sedangkan tanaman yang berwarna coklat merupakan tanaman yang sudah mati.

Tabel 1. Rekapitulasi analisis ragam pengaruh nomor terung dan konsentrasi PEG terhadap persentase hidup eksplan tanaman terung

\begin{tabular}{ccccc}
\hline $\begin{array}{c}\text { Umur } \\
\text { (MSP) }\end{array}$ & $\begin{array}{c}\text { Nomor } \\
\text { Terung }\end{array}$ & PEG & $\begin{array}{c}\text { Interaksi Nomor Terung dan } \\
\text { Konsentrasi PEG }\end{array}$ & KK (\%) \\
\hline 1 & tn & tn & tn & 0 \\
2 & $* *$ & $* *$ & tn & 12.88 \\
3 & $*$ & $* *$ & tn & 22.89 \\
\hline
\end{tabular}

Keterangan: $\left.*^{*}\right)$ berpengaruh sangat nyata $\left.\mathrm{p} \leq 0.01 ; *\right)$ berpengaruh nyata $\mathrm{p} \leq 0.05$; tn=tidak nyata; KK= Koefisien keragaman 
Pengamatan persentase hidup eksplan tanaman dilakukan dari 1 sampai 3 MSP. Nilai rata-rata persentase hidup eksplan adalah 86.14 persen. Tabel 1 menunjukkan bahwa nomor terung memberikan pengaruh tidak nyata pada $1 \mathrm{MSP}$, pengaruh sangat nyata pada 2 MSP dan nyata pada 3 MSP. PEG tidak berpengaruh nyata pada 1 MSP tetapi sudah mulai terlihat berpengaruh nyata pada saat 2 dan 3 MSP. Interaksi kedua faktor tidak memberikan pengaruh nyata pada 1 hingga 3 MSP. Hal ini menunjukkan bahwa nomor terung dan PEG memberikan pengaruh terhadap persentase hidup eksplan tanaman terung.

Tabel 2 menunjukkan bahwa tanaman terung nomor 013 dan 030 merupakan nomor terung yang tidak tahan terhadap cekaman kekeringan pada uji lanjut DMRT. Persentase hidup eksplan tanaman terung nomor 013 dan 030 berbeda nyata dengan nilai persentase hidup eksplan tertinggi yaitu $97.50 \%$ pada nomor 071. Tanaman terung Kania F1, 001, 007, 016, 034, 035, 055, 057, 069, 071, 072, 078, 085, dan 090 merupakan nomor-nomor terung yang tahan terhadap cekaman kekeringan karena tidak berbeda nyata dengan nilai persentase hidup eksplan tertinggi.

Pemberian PEG untuk menurunkan potensial air media diharapkan dapat berfungsi sebagai kondisi selektif untuk menduga respon jaringan yang ditanam terhadap cekaman kekeringan dan mengisolasi sel/jaringan varian yang mempunyai fenotipe cekaman toleran. Efektifitas PEG untuk menduga respon tanaman terung terhadap cekaman kekeringan in vitro diuji dengan mengevaluasi kemampuan bertahan hidup keenam belas nomor terung terhadap cekaman kekeringan.

Tabel 3 menunjukkan bahwa semakin tinggi konsentrasi PEG yang diberikan pada media maka persentase hidup eksplan akan semakin rendah. Berdasarkan uji DMRT
(Tabel 3), persentase hidup eksplan tanaman terung pada media PEG 0, 5 dan $10 \%$ tidak berbeda nyata tetapi berbeda nyata dibandingkan dengan media PEG $15 \%$.

Tabel 2. Persentase hidup enam belas nomor eksplan tanaman terung pada media seleksi kekeringan in vitro

\begin{tabular}{ccc}
\hline \multirow{2}{*}{ Nomor Terung } & \multicolumn{2}{c}{ Eksplan Hidup (\%) } \\
\cline { 2 - 3 } & $2 \mathrm{MSP}$ & $3 \mathrm{MSP}$ \\
\hline Kania F1 & $100.00^{\mathrm{a}}$ & $93.18^{\mathrm{a}}$ \\
001 & $97.50^{\mathrm{ab}}$ & $84.09^{\mathrm{abc}}$ \\
007 & $97.50^{\mathrm{ab}}$ & $93.18^{\mathrm{a}}$ \\
013 & $85.00^{\mathrm{bcd}}$ & $72.73^{\mathrm{bc}}$ \\
016 & $95.00^{\mathrm{abc}}$ & $90.91^{\mathrm{ab}}$ \\
030 & $75.00^{\mathrm{d}}$ & $68.75^{\mathrm{c}}$ \\
034 & $82.50^{\mathrm{cd}}$ & $79.17^{\mathrm{abc}}$ \\
035 & $90.63^{\mathrm{abc}}$ & $84.09^{\mathrm{abc}}$ \\
055 & $93.75^{\mathrm{abc}}$ & $79.55^{\mathrm{abc}}$ \\
057 & $100.00^{\mathrm{a}}$ & $85.00^{\mathrm{abc}}$ \\
069 & $93.75^{\mathrm{abc}}$ & $87.50^{\mathrm{ab}}$ \\
071 & $100.00^{\mathrm{a}}$ & $97.50^{\mathrm{a}}$ \\
072 & $100.00^{\mathrm{a}}$ & $92.50^{\mathrm{a}}$ \\
078 & $91.67^{\mathrm{abc}}$ & $90.00^{\mathrm{ab}}$ \\
085 & $97.22^{\mathrm{ab}}$ & $89.58^{\mathrm{ab}}$ \\
090 & $88.89^{\mathrm{abc}}$ & $85.42^{\mathrm{abc}}$ \\
\hline
\end{tabular}

Keterangan: Angka yang diikuti huruf yang sama pada kolom yang sama menunjukkan hasil yang tidak berbeda nyata pada uji DMRT 5\%

Hal ini menunjukkan bahwa eksplan tanaman terung masih mampu bertahan pada media PEG 5 dan $10 \%$ dengan nilai rata-rata persentase hidup di atas $90 \%$. Berdasarkan selang persentase hidup diketahui bahwa semakin tinggi konsentrasi PEG yang diberikan maka kemampuan membedakan nomor terung yang tahan dan tidak tahan semakin besar. Perlakuan pemberian PEG pada media mempengaruhi keberlangsungan hidup dan pertumbuhan eksplan tanaman terung yang ditanam.

Tabel 3. Pengaruh konsentrasi PEG terhadap persentase hidup eksplan tanaman terung

\begin{tabular}{ccc}
\hline \multirow{2}{*}{ PEG $(\%)$} & \multicolumn{3}{c}{ Eksplan Hidup (\%) } \\
\cline { 2 - 3 } & 2 MSP & 3 MSP \\
\hline 0 & $97.2^{\mathrm{a}}(91.7-100.0)$ & $94.8^{\mathrm{a}}(83.0-100.0)$ \\
5 & $97.0^{\mathrm{a}}(83.3-100.0)$ & $91.9^{\mathrm{a}}(75.0-100.0)$ \\
10 & $94.8^{\mathrm{a}}(67.0-100.0)$ & $89.8^{\mathrm{a}}(50.0-100.0)$ \\
15 & $84.9^{\mathrm{b}}(66.7-100.0)$ & $68.8^{\mathrm{b}}(41.7-100.0)$ \\
\hline
\end{tabular}

Keterangan: Angka yang diikuti huruf yang sama pada kolom yang sama menunjukkan hasil yang tidak berbeda nyata pada uji DMRT 5\%. Angka dalam kurung adalah selang nilai persentase hidup yang didapat dalam pengamatan 
Tabel 4. Uji F persentase hidup eksplan nomor-nomor tanaman terung pada 3 MSP

\begin{tabular}{ccccc}
\hline \multirow{2}{*}{ MSP } & \multicolumn{4}{c}{ Respon Nomor Terung Terhadap } \\
\cline { 2 - 5 } & $0 \%$ & $5 \%$ & $10 \%$ & $15 \%$ \\
\hline 1 & tn & tn & tn & tn \\
2 & tn & tn & tn & $*$ \\
3 & tn & tn & $*$ & tn \\
\hline Keterangan: **) berpengaruh sangat nyata $\leq \leq .01 ; *)$ \\
berpengaruh nyata & $\mathrm{p} \leq 0.05$ & $;$ & tn $=$ tidak \\
& nyata. MSP: Minggu setalah perlakuan.
\end{tabular}

Hasil uji F Tabel 4 menunjukkan bahwa persentase hidup eksplan tanaman terung mulai berbeda nyata pada media PEG $10 \%$ umur 3 MSP dan PEG 15\% umur 2 MSP. Hal ini menunjukkan bahwa media PEG 10 dan $15 \%$ merupakan media yang dapat digunakan untuk seleksi toleransi kekeringan tanaman terung secara in vitro.

Tabel 5 menunjukkan bahwa pada media PEG 10\% umur 3 MSP, tanaman terung nomor 030 terseleksi sebagai nomor terung yang tidak toleran terhadap cekaman kekeringan pada uji lanjut DMRT. Persentase hidup eksplan tanaman terung nomor 030 berbeda nyata dengan nilai persentase hidup eksplan 100\%. Tanaman terung Kania F1, 001, 007, 013, 016, 034, 035, 055, 057, 069, 071, 072, 078, 085, dan 090 merupakan nomornomor terung yang toleran terhadap cekaman kekeringan karena tidak berbeda nyata dengan nilai persentase hidup eksplan $100 \%$. Pada media PEG $15 \%$ umur 2 MSP, tanaman terung nomor 013,030 , dan 034 terseleksi sebagai nomor terung yang tidak toleran terhadap cekaman kekeringan pada uji DMRT. Persentase hidup eksplan tanaman terung nomor 013,030 dan 034 berbeda nyata dengan nilai persentase hidup eksplan $100 \%$. Tanaman terung Kania F1, 001, 007, 016, 035, 055, 057, 069, 071, 072, 078, 085, dan 090 merupakan nomor-nomor terung yang toleran terhadap cekaman kekeringan karena tidak berbeda nyata dengan nilai persentase hidup eksplan $100 \%$.

Media PEG 15\% memiliki kemampuan menyeleksi nomor terung yang tidak toleran cekaman kekeringan cukup banyak dan membutuhkan waktu hingga 2 MSP sedangkan media PEG $10 \%$ memiliki kemampuan menyeleksi nomor terung yang tidak toleran cekaman kekeringan hanya sedikit dan membutuhkan waktu hingga 3 MSP.

Tabel 5. Persentase hidup enam belas nomor eksplan tanaman terung pada media PEG $10 \%$ (3 MSP) dan PEG 15\% (2 MSP)

\begin{tabular}{ccc}
\hline $\begin{array}{c}\text { Nomor } \\
\text { Terung }\end{array}$ & $\begin{array}{c}\text { PEG 10\% } \\
(3 \mathrm{MSP})\end{array}$ & $\begin{array}{c}\text { PEG 15\% } \\
(2 \mathrm{MSP})\end{array}$ \\
\hline Kania F1 & $100.0^{\mathrm{a}}$ & $100.0^{\mathrm{a}}$ \\
001 & $83.3^{\mathrm{a}}$ & $91.7^{\mathrm{ab}}$ \\
007 & $100.0^{\mathrm{a}}$ & $91.7^{\mathrm{ab}}$ \\
013 & $75.0^{\mathrm{ab}}$ & $66.7^{\mathrm{b}}$ \\
016 & $100.0^{\mathrm{a}}$ & $83.3^{\mathrm{ab}}$ \\
030 & $50.0^{\mathrm{b}}$ & $66.7^{\mathrm{b}}$ \\
034 & $75.0^{\mathrm{ab}}$ & $66.7^{\mathrm{b}}$ \\
035 & $91.7^{\mathrm{a}}$ & $83.3^{\mathrm{ab}}$ \\
055 & $91.7^{\mathrm{a}}$ & $83.3^{\mathrm{ab}}$ \\
057 & $83.3^{\mathrm{a}}$ & $100.0^{\mathrm{a}}$ \\
069 & $83.3^{\mathrm{a}}$ & $83.3^{\mathrm{ab}}$ \\
071 & $100.0^{\mathrm{a}}$ & $100.0^{\mathrm{a}}$ \\
072 & $100.0^{\mathrm{a}}$ & $100.0^{\mathrm{a}}$ \\
078 & $100.0^{\mathrm{a}}$ & $83.3^{\mathrm{ab}}$ \\
085 & $100.0^{\mathrm{a}}$ & $91.7^{\mathrm{ab}}$ \\
090 & $100.0^{\mathrm{a}}$ & $75.0^{\mathrm{ab}}$ \\
\hline
\end{tabular}

Keterangan: Angka yang diikuti huruf yang sama pada kolom yang sama menunjukkan hasil yang tidak berbeda nyata pada uji DMRT 5\%

Hal ini menunjukkan bahwa seleksi kekeringan tanaman terung in vitro dapat dilakukan melalui penambahan PEG 10\% pada media dengan biaya yang dikeluarkan lebih murah tetapi waktu seleksi lebih lama atau melalui penambahan PEG $15 \%$ pada media dengan biaya yang dikeluarkan lebih mahal tetapi waktu seleksi lebih cepat.

\section{Persentase Eksplan Berkalus}

Eksplan berkalus adalah eksplan yang membentuk kalus pada bagian jaringan eksplan yang ditanam. Kalus merupakan massa parenkimatis yang belum terdiferensiasi. Kalus pada media PEG 0, 5, 10 dan $15 \%$ terbentuk pada bagian eksplan yang mengalami luka akibat pemotongan. Eksplan berkalus diamati untuk melihat kemampuan berkalus dan perkembangan kalus eksplan pada media PEG. 
Tabel 6. Rekapitulasi analisis ragam pengaruh nomor terung dan konsentrasi PEG terhadap persentase eksplan berkalus pada tanaman terung

\begin{tabular}{|c|c|c|c|c|}
\hline $\begin{array}{l}\text { Umur } \\
\text { (MSP) }\end{array}$ & $\begin{array}{l}\text { Nomor } \\
\text { Terung }\end{array}$ & PEG & $\begin{array}{l}\text { Interaksi } \\
\text { Nomor } \\
\text { Terung dan } \\
\text { Konsentrasi } \\
\quad \text { PEG }\end{array}$ & $\begin{array}{l}\text { KK } \\
(\%)\end{array}$ \\
\hline 1 & th & $* *$ & tn & 14.85 \\
\hline 2 & th & $* *$ & th & 17.83 \\
\hline 3 & $\operatorname{tn}$ & $* *$ & tn & 17.19 \\
\hline \multicolumn{5}{|c|}{$\begin{aligned} \text { Keterangan: } & * * \text { ) berpengaruh sangat nyata } \mathrm{p} \leq 0.01 ; *) \\
& \text { berpengaruh nyata } \mathrm{p} \leq 0.05 ; \mathrm{t}=\mathrm{tidak} \\
& \text { nyata; } \mathrm{KK}=\text { Koefisien keragaman; data } \\
& \text { di transformasi }(\mathrm{x}+0,5)^{1 / 2} \text { sebelum diolah } \\
& \text { menggunakan SAS }\end{aligned}$} \\
\hline
\end{tabular}

Rekapitulasi analisis sidik ragam Tabel 6 menunjukkan bahwa nomor terung dan interaksi kedua faktor tidak memberikan pengaruh terhadap persentase eksplan berkalus tanaman terung mulai dari 1 hingga 3 MSP sedangkan PEG berpengaruh nyata terhadap persentase hidup tanaman terung mulai 1 hingga 3 MSP. Hal ini menunjukkan bahwa PEG memberikan pengaruh terhadap persentase eksplan berkalus pada tanaman terung.

Tabel 7 menunjukkan bahwa semakin tinggi konsentrasi PEG yang diberikan pada media maka persentase eksplan berkalus akan semakin rendah. Persentase eksplan berkalus pada media PEG 0\% umur 3 MSP paling tinggi dibandingkan pada media PEG 5, 10, dan $15 \%$. Persentase eksplan berkalus semakin meningkat dengan semakin bertambah MSP. Berdasarkan uji DMRT, persentase eksplan berkalus pada media PEG 0 dan 5\% tidak berbeda nyata. Persentase eksplan berkalus PEG 0 dan 5\% terlihat berbeda nyata dibandingkan dengan persentase berkalus pada media PEG 10 dan 15\%. Hal ini menunjukkan bahwa eksplan tanaman terung memiliki kemampuan menghasilkan kalus yang sama pada PEG 0 dan 5\%.

Kalus yang terbentuk pada media PEG 0 dan 5\% terlihat berwarna putih kehijauan dan mulai terdiferensiasi menjadi daun pada 2 MSP sedangkan kalus pada media PEG 10 dan $15 \%$ terlihat berwarna coklat. Hartanti et al. (2011) menyatakan eksplan tanaman tembakau membentuk kalus pada media tanpa PEG berwarna putih kehijauan dengan tekstur kompak. Warna putih pada kalus menandakan keberadaan leukoplas yaitu butir-butir plastida yang tidak berwarna dan mengandung pati. Selanjutnya, ketika terpapar cahaya, warna putih berubah menjadi putih kehijauan atau hijau dimana perubahan warna tersebut terjadi akibat sel mulai membentuk klorofil. Robbiani (2010) menjelaskan bahwa kalus yang berwarna coklat merupakan respon oksidasi senyawa fenolik akibat pelukaan suatu jaringan eksplan.

\section{Pertambahan Tinggi Tunas}

Tunas yang diamati pada eksplan yaitu tunas aksilar yang berasal dari stek mata tunas eksplan. Pertambahan tinggi tunas diukur dari dalam botol tanpa mengeluarkan eksplan. Mata tunas eksplan pada media PEG 0 dan 5\% terlihat tumbuh menjadi tunas dan membentuk daun sedangkan mata tunas eksplan pada media PEG 10 dan 15\% terlihat ada beberapa yang tumbuh namun banyak yang tidak tumbuh terutama eksplan pada media PEG $15 \%$.

Tabel 7. Pengaruh konsentrasi PEG terhadap persentase eksplan berkalus pada tanaman terung

\begin{tabular}{cccc}
\hline PEG & \multicolumn{3}{c}{ Eksplan Berkalus (\%) } \\
\cline { 2 - 4 }$(\%)$ & $1 \mathrm{MSP}$ & $2 \mathrm{MSP}$ & $3 \mathrm{MSP}$ \\
\hline 0 & $21.4^{\mathrm{a}}$ & $34.9^{\mathrm{a}}$ & $52.1^{\mathrm{a}}$ \\
5 & $14.1^{\mathrm{ab}}$ & $34.9^{\mathrm{a}}$ & $47.9^{\mathrm{a}}$ \\
10 & $10.9^{\mathrm{b}}$ & $25.0^{\mathrm{a}}$ & $27.1^{\mathrm{b}}$ \\
15 & $0.0^{\mathrm{c}}$ & $2.1^{\mathrm{b}}$ & $2.6^{\mathrm{c}}$ \\
\hline
\end{tabular}

Keterangan: Angka yang diikuti huruf yang sama pada kolom yang sama menunjukkan hasil yang tidak berbeda nyata pada uji DMRT 5\%

Tabel 8. Rekapitulasi analisis ragam pengaruh nomor terung dan konsentrasi PEG terhadap pertambahan tinggi tunas eksplan tanaman terung

\begin{tabular}{|c|c|c|c|c|}
\hline $\begin{array}{l}\text { Umur } \\
\text { (MSP) }\end{array}$ & $\begin{array}{l}\text { Nomor } \\
\text { Terung }\end{array}$ & $\begin{array}{c}P E \\
G\end{array}$ & $\begin{array}{l}\text { Interaksi } \\
\text { Nomor } \\
\text { Terung dan } \\
\text { Konsentrasi } \\
\quad \text { PEG }\end{array}$ & $\begin{array}{l}\text { KK } \\
(\%)\end{array}$ \\
\hline 1 & $*$ & $* *$ & tn & 5.73 \\
\hline 2 & tn & $* *$ & th & 10.23 \\
\hline 3 & tn & $* *$ & tn & 15.88 \\
\hline \multicolumn{5}{|c|}{$\begin{aligned} \text { Keterangan: } & \left.* *) \text { berpengaruh sangat nyata } \mathrm{p} \leq 0.01 *^{*}\right) \\
& \text { berpengaruh nyata } \mathrm{p} \leq 0.05 ; \text { tn }=\text { tidak } \\
& \text { nyata; } \mathrm{KK}=\text { Koefisien keragaman; data } \\
& \text { ditransformasi }(\mathrm{x}+1)^{1 / 2} \text { sebelum diolah } \\
& \text { menggunakan SAS }\end{aligned}$} \\
\hline
\end{tabular}


Tabel 8 menunjukkan bahwa nomor terung memberikan pengaruh sangat nyata terhadap pertambahan tinggi tanaman terung hanya pada 1 MSP dan tidak berbeda nyata pada 2 dan 3 MSP sedangkan PEG berpengaruh sangat nyata terhadap pertambahan tinggi tunas tanaman terung mulai 1 hingga 3 MSP. Interaksi kedua faktor tidak memberikan pengaruh nyata pada 1 hingga 3 MSP. Hal ini menunjukkan bahwa PEG memberikan pengaruh terhadap pertambahan tinggi tunas tanaman terung.

Pembentukan tunas didefinisikan sebagai pembentukan daun dimana proliferasinya sangat mempengaruhi pertumbuhan dan perkembangan tanaman. Menurut George et al. (2008), pembentukan tunas pada kultur in vitro lebih sering diinduksi pertama kali dibandingkan pembentukan akar supaya mekanisme fotosintesis kultur berlangsung lebih optimal. Semakin tinggi konsentrasi PEG yang diberikan pada media maka pertambahan tinggi tunas eksplan semakin rendah. Pertambahan tinggi tunas tanaman terung pada media PEG 0\% paling tinggi dibandingkan pada media PEG 5, 10 dan 15\% (Tabel 9). Berdasarkan uji DMRT, eksplan tanaman terung pada PEG 10 dan 15\% memiliki pertambahan tinggi tunas yang tidak berbeda nyata tetapi berbeda nyata dibandingkan dengan pertambahan tinggi tunas eksplan tanaman terung pada PEG 0 dan 5\%.

Eksplan pada media PEG 15\% memiliki pertambahan tinggi tunas terendah dengan nilai $0.00 \mathrm{~cm}$ (Tabel 9). Hal ini menunjukkan bahwa PEG $15 \%$ pada media tidak dapat ditoleransi oleh eksplan untuk mendukung pertumbuhan tunas. Eksplan pada media PEG $15 \%$ tidak mengalami pertambahan tinggi mulai 2 dan 3 MSP. Menurut Kong et al. (1998) PEG dalam media dapat menurunkan foliferasi dan pertumbuhan jaringan eksplan dan regenerasi tunas. Potensial osmotik media tumbuh merupakan faktor penting yang berpengaruh terhadap poliferasi tunas. PEG $15 \%$ yang ditambahkan ke dalam media mengakibatkan potensial air media lebih rendah dibandingkan potensial air sel sehingga senyawa makronutrien yang terkandung di dalam media tidak dapat berpindah ke dalam sel secara osmosis yang mengakibatkan tunas tidak tumbuh dan berkembang.

\section{Jumlah Daun}

Jumlah daun yang diamati adalah jumlah daun pada eksplan yang telah membuka sempurna per botol. Perhitungan jumlah daun dimulai dari daun baru yang muncul. Daun tanaman terung sudah mulai tumbuh pada 1 MSP pada media PEG 0 dan 5\% sedangkan daun pada media PEG 10 dan 15\% hampir tidak ada karena tidak tumbuhnya mata tunas.

Tabel 9. Pengaruh konsentrasi PEG terhadap pertambahan tinggi tunas eksplan tanaman terung

\begin{tabular}{cccc}
\hline \multirow{2}{*}{$\begin{array}{c}\text { PEG } \\
(\%)\end{array}$} & \multicolumn{3}{c}{$\begin{array}{c}\text { Pertambahan Tinggi Tunas per } \\
\text { Eksplan }(\mathrm{cm})\end{array}$} \\
\cline { 2 - 4 } & $1 \mathrm{MSP}$ & $2 \mathrm{MSP}$ & $3 \mathrm{MSP}$ \\
\hline 0 & $0.25^{\mathrm{a}}$ & $0.43^{\mathrm{a}}$ & $0.36^{\mathrm{a}}$ \\
5 & $0.14^{\mathrm{b}}$ & $0.23^{\mathrm{b}}$ & $0.14^{\mathrm{b}}$ \\
10 & $0.06^{\mathrm{c}}$ & $0.04^{\mathrm{c}}$ & $0.02^{\mathrm{c}}$ \\
15 & $0.01^{\mathrm{c}}$ & $0.00^{\mathrm{c}}$ & $0.00^{\mathrm{c}}$ \\
\hline Keterangan: Angka yang diikuti huruf yang sama pada \\
kolom yang sama menunjukkan hasil \\
yang tidak berbeda nyata pada uji \\
DMRT 5\%
\end{tabular}

Tabel 10. Rekapitulasi analisis ragam nomor terung dan konsentasi PEG terhadap jumlah daun per botol eksplan tanaman terung

\begin{tabular}{|c|c|c|c|c|}
\hline $\begin{array}{l}\text { Umur } \\
\text { (MSP) }\end{array}$ & $\begin{array}{l}\text { Nomor } \\
\text { Terung }\end{array}$ & PEG & $\begin{array}{l}\text { Interaksi } \\
\text { Nomor } \\
\text { Terung dan } \\
\text { Konsentrasi } \\
\quad \text { PEG }\end{array}$ & $\begin{array}{l}\text { KK } \\
(\%)\end{array}$ \\
\hline 1 & th & $* *$ & tn & 10.96 \\
\hline 2 & tn & $* *$ & tn & 16.85 \\
\hline 3 & tn & $* *$ & tn & 18.92 \\
\hline \multicolumn{5}{|c|}{$\begin{array}{r}\text { Keterangan: } * *) \text { berpengaruh sangat nyata } \mathrm{p} \leq 0.01 ; *) \\
\text { berpengaruh nyata } \mathrm{p} \leq 0.05 ; \mathrm{t}=\text { tidak } \\
\text { nyata; KK= Koefisien keragaman; data } \\
\text { ditransformasi }(\mathrm{x}+3){ }^{1 / 2} \text { sebelum diolah } \\
\text { menggunakan SAS, MSP = minggu } \\
\text { setelah perlakuan }\end{array}$} \\
\hline
\end{tabular}

Tabel 11. Pengaruh konsentrasi PEG terhadap jumlah daun per botol eksplan tanaman terung

\begin{tabular}{cccc}
\hline PEG & \multicolumn{3}{c}{ Jumlah Daun Botol $^{-1}$} \\
\cline { 2 - 4 }$(\%)$ & $1 \mathrm{MSP}$ & $2 \mathrm{MSP}$ & $3 \mathrm{MSP}$ \\
\hline 0 & $1.0^{\mathrm{a}}$ & $2.9^{\mathrm{a}}$ & $3.6^{\mathrm{a}}$ \\
5 & $0.4^{\mathrm{b}}$ & $1.7^{\mathrm{b}}$ & $2.1^{\mathrm{b}}$ \\
10 & $0.1^{\mathrm{c}}$ & $0.3^{\mathrm{c}}$ & $0.5^{\mathrm{c}}$ \\
15 & $0.0^{\mathrm{c}}$ & $0.0^{\mathrm{c}}$ & $0.0^{\mathrm{c}}$ \\
\hline
\end{tabular}

Keterangan: Angka yang diikuti huruf yang sama pada kolom yang sama menunjukkan hasil yang tidak berbeda nyata pada uji DMRT 5\%, MSP = minggu setelah perlakuan 
Tabel 10 menunjukkan bahwa nomor terung memberikan pengaruh tidak nyata terhadap jumlah daun pada 1 hingga 3 MSP sedangkan PEG berpengaruh sangat nyata terhadap pertambahan tinggi tunas tanaman terung mulai 1 hingga 3 MSP. Interaksi kedua faktor tidak memberikan pengaruh nyata pada 1 hingga 3 MSP. Hal ini menunjukkan bahwa PEG memberikan pengaruh terhadap jumlah daun tanaman terung.

Daun pada tanaman terbentuk dari tunas yang merupakan calon vegetatif tanaman yang berupa kuncup (gemmae). Tabel 11 menunjukkan bahwa semakin tinggi konsentrasi PEG pada media maka jumlah daun eksplan yang tumbuh semakin rendah. Jumlah daun pada media PEG $0 \%$ paling tinggi dibandingkan pada media PEG 5, 10 dan $15 \%$. Berdasarkan uji DMRT, jumlah daun per botol pada media PEG 10 dan $15 \%$ tidak berbeda nyata tetapi berbeda nyata dibandingkan dengan jumlah daun per botol pada media PEG 0 dan 5\%. Eksplan tanaman terung mampu membentuk daun hanya pada pada media PEG 0, 5, dan 10\%. Eksplan pada media PEG $15 \%$ tidak menghasilkan daun pada 1 hingga 3 MSP. Hal ini terjadi karena tidak tumbuhnya tunas pada eksplan. Hal ini menunjukkan bahwa PEG $15 \%$ pada media tidak dapat ditoleransi oleh eksplan untuk membentuk daun.

\section{KESIMPULAN}

Penambahan PEG pada media in vitro mampu menurunkan persentase hidup eksplan, persentase eksplan berkalus, pertambahan tinggi tunas, dan jumlah daun tanaman terung. Tanaman terung Kania F1, 001, 007, 016, 034, 035, 055, 057, 069, 071, 072, 078, 085, dan 090 merupakan nomor-nomor tanaman terung yang toleran terhadap kekeringan. Media PEG $10 \%$ dan $15 \%$ merupakan media yang dapat digunakan sebagai media seleksi kekeringan untuk tanaman terung secara in vitro.

\section{DAFTAR PUSTAKA}

[BPS] Badan Pusat Statistik. 2014. Produksi sayuran di Indonesia 1997-2013. http://www.bps.go.id/tab_sub/view.php ?kat $=3 \&$ tabel $=1 \&$ daftar $=1 \&$ id_subyek $=$ $55 \&$ notab=70. [20 Sepember 2014].

[Deptan]. 2014. Volume impor dan ekspor sayuran tahun 2012. http://hortikultura. pertanian.go.id/index.php?option=com content $\&$ view $=$ article $\&$ catid $=57 \% 3 \mathrm{Aek}$ spor-impor\&id=336\%3Anilai-impor-aekspor-sayuran-th-2012\&Itemid $=702$. [20 September 2014].

Efendi, R., Suwardi, M. Isnaini. 2010. Metode dan penentuan karakter seleksi genotipe jagung terhadap cekaman kekeringan pada fase awal vegetatif. Pekan Serealia Nasional; 2010; Maros, Indonesia. Balai Penelitian Tanaman Serealia. 230-240, Maros.

Elimasni, I. Nurwahyuni, M.Z. Sofyan. Inisiasi in vitro biji muda terong belanda (Solanum betaceum Cav.) Berastagi Sumatera Utara pada komposisi media dan zat tumbuh yang berbeda. Jurnal Biologi Sumatera. 1(1): 15-19.

[FAO] Food and Agriculture Organization. 2012. Top production eggplant-aubergines. http://faostat.fao.org/site/339/default. Aspx. [14 Juli 2014].

George, E., M. Hall, G.J. Klerk. 2008. Plant Propagation by Tissue Culture 3rd Edition. Springer Publisher Netherlands (BL).

Hartanti, Nurhidayati, Muryono. 2011. Budidaya tanaman tembakau (Nicotiana tabacum L. var Prancok 95) pada cekaman kekeringan polyethylene glycol (PEG) secara in vitro. Institut Teknologi Sepuluh Nopember. Surabaya.

Hastuti, L.D. 2007. Terung tinjauan langsung ke beberapa pasar di Kota Bogor. Skripsi. Universitas Sumatera Utara. Medan.

Kong, L., S.M. Attree, L.C. Fowkw. 1998. Effects of polyethylene glycol and methylglyoxal bis (guanylhydrazone) on endogenous polyamine levels and somatic embrio maturation in white 
spruce (Picea glauca). Plan Sci 133: 211-220.

Mexal, J., J.T. Fisher, Osteryoung, C.P. Patrick. 1975. Oxygen availability in polyethyl-ene glycol solutions and its implications in plant-water relations. Plant Physiol. (55): 20-24.

Rahayu, E.S., E. Guhardja, S. Ilyas, Sudarsono. 2005. Polietilena glikol (PEG) dalam media in vitro menyebabkan kondisi cekaman yang menghambat tunas kacang tanah (Arachis hypogaea L.). Hayati (11): 39-48.

Robbiani, Daniar. 2010. Pengaruh kombinasi naphthalene acetic acid (NAA) dan kinetin pada kultur in vitro eksplan daun tembakau (Nicotiana tabacum L. var. Prancak 95). Skripsi. Institut Teknologi 10 November Surabaya. Surabaya.

Zulkarnain. 2010. Dasar-Dasar Hortikultura. PT Bumi Aksara.6-9p. Jakarta. 